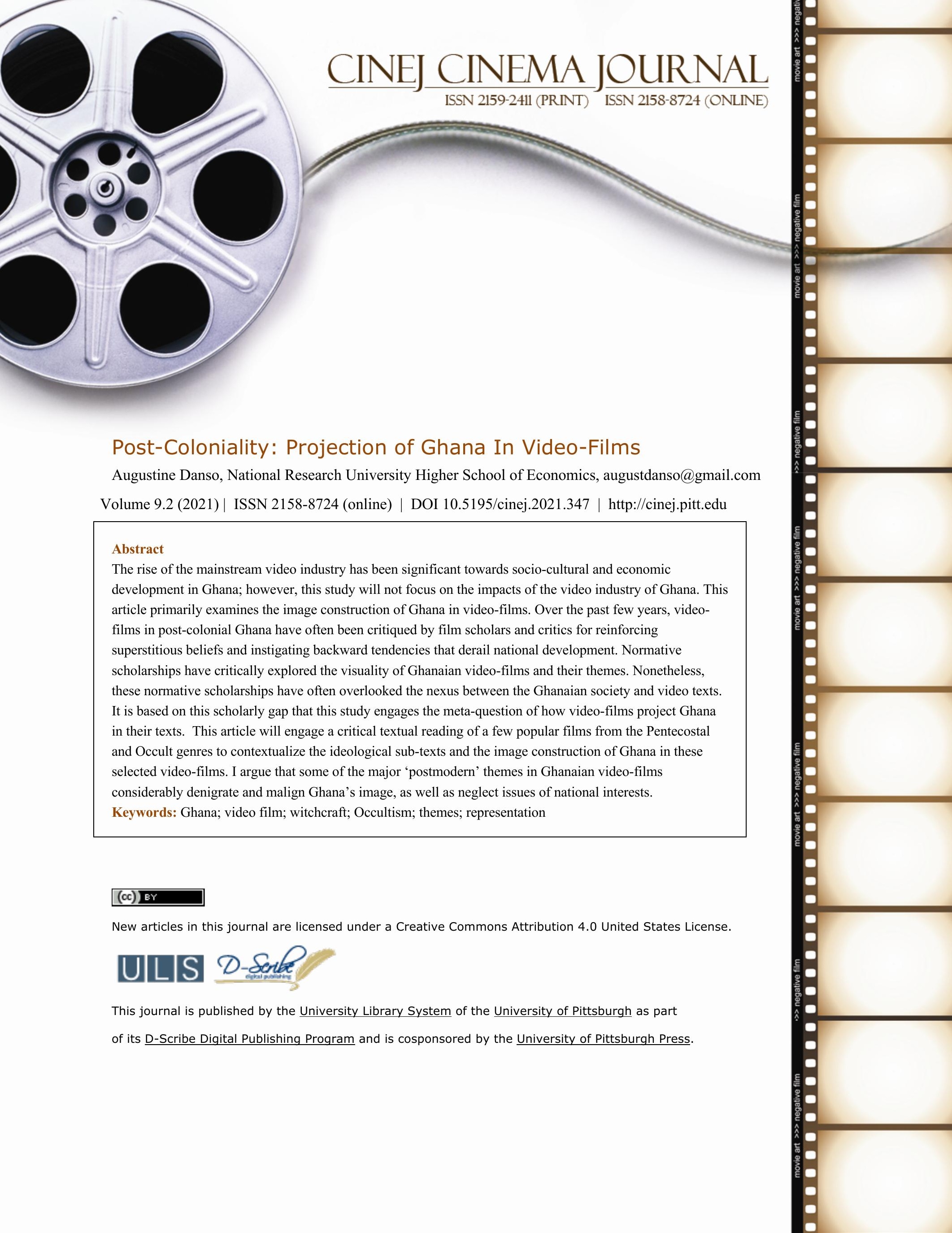




\section{Post-Coloniality: Projection of Ghana In Video-Films}

\section{Augustine Danso}

"Film, in common with all other sorts of creative artifacts, is a particularly rich source for the perceptions and assumptions held within groups and societies; and film, finally, is obviously a central source for the study of film itself, and how it is exploited, consciously or unconsciously, by governments and private individuals to put over particular assumptions about society, or propagandist messages"(Marwick, 1989, p. 319).

A major feature of films is their direct and ingrained relationship between society and people. As a powerful mediatory medium, films reflect what happens in a society and in the lives of people or audiences. Thus, films have the inarguable power to instigate opinions, impressions, and assumptions about a particular society and people, for instance, "Hotel Rwanda (2004)", which was directed by Terry George reflects the fatal 1994 genocide between the Hutus and Tutsis that claimed over one million lives in Rwanda. This study specifically examines how video texts project the image of Ghana. The analysis will be based predominantly on a critical reading of contemporary post-colonial film texts in Ghana. This paper critically engages the selected film texts to uncover the assumptions and latent meanings of their narratives about the Ghanaian society. In framing this study's argument, this paper employs the term post-coloniality to explore the ideologies and practices that shape contemporary Ghanaian cultures, societies, and economy from the perspective of film practice.

Post-colonial Ghanaian video films have been liable to some key criticisms from film scholars and critics. These criticisms, for the most part, are directed towards substandard video-film contents and the incorporation of various globalized narrative schemas in Ghanaian video films such as sex with nudity, gangsterism among others. Film scholar, Aveh (2010) argues that these scenes have been unsuccessful due to the inability to create convincing stunts and visual effects. Shallow stories and weak plots coupled with poor cinematography render these video films sub-standard (p.131). 
As theorized by Nanbigne (2016) “...patrons of cultural products are not mere passive receivers of texts but that they are usually actively involved in creating the meanings generated in those texts. Therefore, we can infer that these texts are close approximations of the cultural characteristics of the producers and consumers" (p.625). The appropriation of the genre of action- drama video-films in addition to sex with considerable nudity are often dictated by consumerism among film audiences in Ghana. As Adjei (2014) argues, the new entrants to the film industry were driven more by commercial instincts than a desire to create a system that captures the vision of Osagyefo Kwame Nkrumah, who saw the indigenous Ghanaian or African film as a political, cultural and decolonization weapon.

\section{Theories of 'Post-Coloniality'}

This section, however, attempts to offer theoretical definitions and meanings of 'post-coloniality' or postcolonialism for this study's context. Post-colonial theory has rarely been integrated into the paradigm of cinema studies, although the term has direct links with media and film studies. As affirmed by Ponzanesi (2018), both postcolonial theory and film studies emerged at the end of the 1970s with the development of semiotic theory and poststructuralist thought. Both areas engage intensively with the field of representation, implying the ways in which a language, be it cinematic or otherwise, manages to convey reality as "mediated" and "discursive," and therefore influenced by power relations (p.1). She further theorizes that the term has critically contributed to revisiting the representation of the Other, addressing long-standing tropes and stereotypes about cultural difference and racial otherness. This implies new interventions on how visual representations are implicated in the policing of boundaries between East and West, between Europe and the Rest, the self and the other, undoing or rethinking the ways in which the visual field conveys operation of a mastery that needs to be undone and decoded (Ponzanesi, ibid, p.1). 
Amad (2013) argues that the legacy of post-colonialism on visual culture has been a reinvestigation of the role of a number of visual technologies (e.g., photography, postcards, advertisements, cinema) and sites (e.g., world's fairs, zoos, natural history museums, colonial expositions) that in the nineteenth and early twentieth centuries contributed to, reflected, or refracted the specular antagonism underpinning diverse colonial encounters (p.50). According to Nash et al (2013), "post-colonialism has been since its inception in that latter part of the twentieth century. Riven through with debate and controversy. Starting out in a Marxist discourse as a term that was theoretically distinguished from neocolonialism (that is, the belief in continued economic and political control of now independent countries by former colonizers in the West). It described the bureaucratically overdeveloped and militaristic states emerging after, but in continuation of, colonial occupation, which exacerbated or at least maintained underdevelopment through the collusion between the state, elites and western corporate interests". Lazare and Van Arde (2007) theorize that post-coloniality centers "around social histories, cultural differences and political discriminations that are practiced and normalized by colonial and imperial machineries" (p.1174). In the subsequent parts of this study, I will attempt to critically interrogate the ideological orientations that underpin the major postmodern themes of sex, love, gangsterism, femme fatale, Christianity against local traditions, witchcraft, and occultism. A few of the chosen video texts are ten to twenty years old. This approach is to primarily establish the continuity and change in the major themes in Ghanaian video-films.

\section{MAJOR THEMES IN GHANAIAN VIDEO-FILMS.}

\section{Pentecostal- Charismatic Genres}

Pentecostalism has created new public spheres which has evolved in Ghana after the return to democracy, and the aftermath of liberalization and commercialization of the hitherto state-owned and state-controlled media in 1992. Pentecostal-charismatic churches have understood the power of media to reach people, thereby creating a 'Pentecostally'-inclined Christian public (Meyer, 2002, p. 69). The Ghana video industry which emerged in the 1980s and took off in the 1990s following the liberalization of the media and Ghana's interest in democracy was 
characterized by popular Pentecostal expressive forms. Distinct of this Pentecostal genre are their religiously inherent representations. The Pentecostal video texts particularly visualize teachings, directives, and lessons of spirituality to film audiences. This new identity considerably portrays a society that is ridden with evil, and it would take the intervention of a spiritually fortified 'Pentecostalist' or pastor to save such a society from these woes, and subsequently bless suffering people with happiness and wealth.

As a crucial section of this paper, this study explores the major thematic concerns that underlie contemporary post-colonial Ghanaian video texts. The study consciously decouples the synopses and textual readings of film texts from the analysis of image projection of Ghana. This approach is to establish a critical understanding of the mediation and representations in the dominant themes in Ghanaian video texts

\section{Christianity Against African Traditional Religion}

Pentecostal video texts utilize this theme to offer audiences with religious experience. This thematic concern seeks to direct Ghanaian film audiences on how to spiritually combat the evil that relates to the Ghanaian and African traditional religion. Individual filmmakers perceive it as crucial to visualize popular rumors and stories that are replete with evil spirits, mysterious powers and in Ghana. In the particular case of the Pentecostal video texts which mainly visualize the dualism between God and evil, modernity is perceived as a Christian project where divine forces are portrayed to be the only solution to man's survival and prosperity. At the end of their storylines, they regularly portray good triumphing over evil. As a key characteristic of these video texts, they most often end with an epigram such as "Glory be to God" and "Praise the Lord" after divine powers defeat evil spirits. As exemplified in Samuel Nyamekye's video film 'Asoreba' (2006), which is set in the dualism between God and evil, offers a fierce spiritual battle between the Christian God and evil, where the former defeats the latter. In this video-film, the main character, Asabea vehemently entreats Awurama to beseech an African traditional priest (adurowura). This directive was geared towards soliciting for spiritual assistance to aid 
Awurama reunites with her 'strayed' husband (Takyi), who happened to have an amorous relationship with the character, Afrakoma. Consequently, the African traditional priest spiritually breaks down Afrakoma with epilepsy. As the storyline unfolds, Awurama happily re-unites with her husband, Takyi. The spiritual battle between God and evil is portrayed when a Christian pastor intervenes with striking prayers to save and restore Afrakoma's life from Epilepsy. In the film's denouement, Asabea is spiritually struck by divine forces that compel her to confess her evil deeds openly.

\section{Witchcraft and 'Juju'}

Another major theme in post-colonial Ghanaian video text is witchcraft and 'juju' (black magic). In their escapist form, these narratives portray evangelists, prophets and spouses normally on the virtuous side, whiles unfaithful husbands, troubling mothers-in-law, immoral ladies, wicked aunties, and bad companions are depicted in evil engagements, which work under the influence of satanic forces. These powers are normally part of the class of the 'demonic spirits' who are allied with Satan and do everything possible to make life unbearable for individuals and redirect them from God.

This major theme is exemplified in, perhaps, the video-film with the most sequels in Africa, "Kyeiwaa" (2006) by Danfo B.A. This film is set in a Ghanaian society where witchcraft is deeply ridden amongst the people. The storyline mainly centers around the main character, Kyeiwaa, who is portrayed as a ruthless and an uncompromising witch. As the story unfolds, she regularly engages nocturnal meetings with her counterparts (witches and wizards) to hatch evil plans against people, family members and society. Kyeiwaa spiritually stymies individuals of development, causes death and subject people to untreatable and unbearable sicknesses through her powerful witchcraft.

Ghost Vengeance

CINEJ Cinema Journal: Post-Coloniality: Projection of Ghana In Video-Films

Volume 9.2(2021) | ISSN 2158-8724 (online) | DOI 10.5195/cinej.2021.347 | http://cinej.pitt.edu 
A distinctive feature of Ghanaian film texts is the recurring representation of ghost and their desire for vengeance. The narrative of ghost vengeance in Ghanaian video films fictionalizes a murdered character wreaking spiritual and physical vengeance on his killers. Often these murdered characters undertake their vengeance by incurring madness, endless torture and eventual death on their killers. As depicted in "In 6 months" (2018) by Eastwood Asempa chronicles the hardships of living in urban areas in Ghana. Kobby, who is frustrated of his inability to cater to the needs of his family is cogently convinced by a friend to join an occult group, with the hope of making money and acquiring wealth overnight. His wife, Bridget, and his unborn baby die as a result of being offered as spiritual sacrifice to the occult force. In the film's climax, Bridget, who returns as a ghost haunts Kobby and subsequently kills him as a form of revenge.

\section{Femme Fatale}

Widely known as "women are dangerous" among Ghanaian film audiences, this theme often runs through the most popular Ghanaian video-films. This theme often portrays a seductive lady who baits men into dangerous situations. Frank Rajah's film, 'The Game' (2010) is portrayed in a Western-like setting, which is characterized by Western costumes, soundtrack, language, and other forms of Western mannerisms by the characters. The video film depicts a fierce antipathy between two brothers, Teddy, and Bill, who fights over an insurance policy. In a clandestine attempt to claim sole ownership of the insurance policy, the younger brother, Teddy, hires the service of a female assassin, Shennel to sexually seduce and murder Bill.

\section{Occultism/ Money Rituals}

Occultism which is locally known as 'Sika Duro' or 'Sakawa' is a major thematic concern that popularizes postcolonial Ghanaian video texts. In its escapist form, these video texts visualize characters presenting sacrifices to traditional priests and occult forces for their favors. In their narratives, the allegoric explanation of 'Sakawa' is 
that men must sacrifice their healthy relationships with their families, wives, children, and friends to become wealthy and relevant in the modern capitalist economy. In Eastwood Asempa's video film 'In 6 Months' (2018), Kobby, upon the advice of his friend resorts to an occult force for financial gains and wealth. He sacrifices the lives of his wife and the unborn baby for the favors of the occult force. Kobby's dreams of becoming affluent are fulfilled, but he loses his family in the cause.

\section{Love and Sex}

As a major theme in Ghanaian video texts, narratives of sex and love are inherent in the plot of most commercial video films in Ghana. Their settings are mainly characterized by western lifestyles, costumes, music, and food. Their storylines often unfold the scenes of "love at first sight" where a man and a woman fall in love on their first encounter. In Socrate Sarfo's “Hot Fork” (2010) video film, In Socrate Sarfo's "Hot Fork” (2010) video film, Efa introduces Adobea to her boyfriend, Duah, as her trusted friend. Adobea, who gets mesmerized by the looks of Efa's boyfriend, engages in a discreet and an amorous relationship with him. This video text depicts Adobea and Duah explicitly engaging in intimacy with nudity. Comparably in Eastwood Asempa's video film "In 6 Months" (2018), Fred, engages in an illicit sexual relation with Philippa, a married woman. As the film's narrative unfolds, Fred clandestinely frequents Philippa's house, whiles her husband is away for a series of explicit sexual engagements.

\section{Gun Battles and Gangsterism}

The thematic focus on gun-wielding battles, martial art fights and gangsters has been a newly incorporated motif in contemporary post-colonial Ghanaian video-films. In the recent past, Ghanaian video-films exploit the Hollywood genre of action movies. These video texts often depict brutal scenes with criminals on rampage, who

kill without leniency. In other narratives, this theme visualizes merciless and rebellious individuals murdering 
citizens. Their storylines further unfold gun-wielding battles and martial arts fights between armed robbers and the police

In an action-drama setting, 'Hard Target' (2018) by Samuel Appiah unfolds a narrative of gun battle and martial art fight between an armed robbery group (gangsters) and the Ghana Police Service. This video text portrays a vile armed robbery leader, Bombey, who terrorizes, tortures, and kills citizens without mercy. Infuriated by the police service's plan to foil the activities of the entire armed robbery group and subsequently cause their arrest, Bombey abducts the niece and daughter of the police commander to compromise and preclude an imminent attack on his team by the police service. As the plot unfolds, the resistance provokes a fierce, ruthless gun-battle and martial art fight between the police service and the armed robbery team. The film's resolution is characterized by the arrest of Bombey and the death of the armed robbery members following a decisive gun battle with the police personnel. In Frank Rajah's video film, The Game (2010), Teddy engages the services of a professional assassin, Shennel, to murder his brother, Bill, for a family property. As the narrative unfolds, this leads to a fierce gun-battle between Bill's allies and Teddy.

As discussed, the above textual analysis of the selected video texts reveals that the dominant thematic concerns that underpin the popularity of contemporary Ghanaian video films visualize diverse representations and narratives that attempt to reflect and mediate societal happenings in Ghana. In the subsequent section, this study will attempt to integrate the synopses of the films to engage if a vision, perspective and image of Ghana is being projected or whether a fictionalized image is being projected in these themes.

\section{The Image of Ghana in Video Texts.}

"Unity of the nation is constructed in narrative form through stories, images, symbols and rituals which lend themselves to "shared" meanings of nationhood. National identity is a constructive representation of shared experiences and history, told through stories, literature, popular culture and of course, television" (Nanbigne, 2013, p. 13) 
Video films, as a product of popular culture, have been a phenomenal tool for the dissemination of information and stories. From the Ghanaian perspective, these texts are characterized by myths, fiction, non-fictions, and symbols that create a sense of belonging in Ghanaian audiences. Based on the video text analysis, movies reflect some aspects of the Ghanaian society whether realistically or exaggerated. All the films produced reflect various aspects of people's lives, ways of thinking, and their general outlook on life in the Ghanaian context. This part establishes the projection of Ghana in the already discussed dominant themes in Ghanaian film texts To begin with, the popular thematic concern of witchcraft and African traditional religion against Christianity creates new identities in Ghanaian video film practice. This motif portrays Ghanaian traditions, culture and mainly traditional priests and 'evil' characters surrendering to divine forces that relate to Christianity. Their narratives visualize and connect death, sickness, and poverty with local traditions in Ghana, whiles wealth and prosperity are projected as Christian products.

Within the context of colonial films and their narratives, British colonial films often projected the African and specifically the Ghanaian society as a wilderness, cultureless and a place of depravity characterized by backward, evil, and superstitious religion (Yanney, 1973, pp. 3-4). Colonial films such as "Terrible People and Mansion of Mystery" suggested through their narratives that local traditions and culture in Africa should be replaced with the Euro-Christianity religion. In a direct comparison, contemporary post-colonial Ghanaian video texts 'Asoreba' (2007) depicts an African traditional priest, who spiritually casts a spell on the character, Afrakoma. Similarly, 'Marijata' (2000) portrays a traditional Ghanaian priest residing in a deep forest, who destroys and kills innocent people with black magic. 'Kyeiwaa' (2006) also depicts a wicked witch, who destroys people and society. The intervention of a spiritually fortified Christian pastor often defeats and triumphs over these forces. These representations do not only embrace notions that support the colonial perception of African barbarity that, as a "wilderness", Ghanaians and Africans still live on trees and forest with wild creatures, but also portrays Ghana as a country whose traditions and culture are rife with destruction and evil practices. The narratives in these video texts also project Ghanaians as overly obsessed with spiritualism and abstract forces. Furthermore, 
Ghanaian traditional religion which is portrayed as submitting to Euro-Christianity gives credence to white supremacist ideology and cultures. What is considerably disorienting in these video texts is that their narratives, to an extent, propose that Ghanaian film audiences should rebuff everything African for Western lifestyles, ideologies, and cultures as a form of civilization. Much as this representation is problematic, a careful observation of such themes heighten skepticism of whether contemporary Ghanaian filmmakers are abreast of the practices of the African traditionalists as healers, counselors, advisors, and repository of knowledge in the Ghanaian society. The absence of these realistic representations of African traditionalists renders this theme flawed, quixotic and a misrepresentation of the Ghanaian society.

From the perspective of ghost vengeance theme in popular Ghanaian video films, Ghanaian movie producers employ this as a form of poetic justice, as exemplified in the film text In 6 Months' (2018). This theme, in its fictionalized form attempts to reflect the popular rumor, belief and thoughts of ghost return or vengeance in the Ghanaian society. This is a dominant thematic concern worth interrogating on the grounds that this narrative considerably proposes, to film consumers or audiences that, on the off chance that they cannot get equity through the normal civic or legal institutions they should have a recourse to fate; believing that fate would churn out its own package of justice.

In context, this representation mythologizes Ghana in a way that reinforces the colonial perception about Africans and specifically Ghanaians as "superstitious, uncivilized and irrational" and a country, where citizens resort to fate for justice and not the legal institutions. Much as this representation cannot be disputed as a reflection of the belief in the ghost among some Ghanaians, its narratives are often fictionalized and unrealistic in its attempt to reflect Ghana. Specifically, these film texts do not necessarily reflect the convictions of the Ghanaian filmmaker, but also the general ideas and thoughts of their film consumers or audiences. The existence of multitudinous civic institutions including competent judiciary systems that mediate cases and administer justice reveals Ghanaians' trust in civic institutions for their needs instead of 'fate'. This theme is thus, 
considerably flawed as it is exaggerated, in that it creates the impression of country whose entire citizens frequent fate for their needs.

Occultism and ritual money in Ghanaian video films, as epitomized in 'In 6 Months' (2018) video texts dwells on consumerism and individualism of a fickle generation who are keen on the simple life, swift acquisition of riches and where the virtues of diligent work and decency have been conspicuously lost. As against issues of national interest, the narratives in these video films portray Ghana as a place where younger generations reject the rewards of hard work in favor of shady and murky acts that fetch wealth overnight.

As exemplified in the video films "The Game" (2010) and "Kyeiwaa" (2006), the narratives of femme fatale theme portray women as diabolic for being witches, often possessing evil spirits, or engaging in iniquitous deeds. The narratives in these video texts often provoke questions whether the cause for gender parity is misconstrued or lost from the African perspective. This thematic focus portrays Ghana as a country where women are demonized, stigmatized, mistreated, and marginalized due to certain false impressions. The phenomenon of women occupying higher positions in the socio-political space in contemporary Ghana renders the theme unrealistic, tenuous and a figment of the imagination of filmmakers.

Ogunleye (2003) argues that "the globalized world is united under the sway of a visual culture principally dominated by the United States of America and Europe" (p. 1). Against this backdrop, it is no coincidence that the video film industry of Ghana (Ghallywood) is named after the "wood" model of the American film industry, Hollywood. Post-colonial Ghanaian filmmakers often imitate the techniques of the West, for example, camera angles, music, storylines, and costumes. Major western themes of gangsterism, gun-wielding battles, sex with nudity in popular Ghanaian video texts reinforce the colonial notion of Ghana and Africa as a "cultureless" country that leans on Western cultures and lifestyles. Romance, sex, and love are considerably not insignificant themes, but the inability of Ghanaian filmmakers to domesticate these narratives to suit the Ghanaian sociocultural context in a form of education makes these themes irrelevant and problematic. It is also crucial to indicate that Ghana is characterized by diverse cultural traditional practices and forms, and thus, the conscious 
or unconscious omission of traditions and cultures in video texts misrepresents the Ghanaian society. Consequently, the recurring western themes in Ghanaian film texts simply pushes Western cultural supremacy and fail to elevate consciousness on national culture, heritage, and traditions in Ghana.

\section{Conclusion}

In contemporary post-colonial Ghana, consumerism and the economics of video film production are key dictates of film content. The absence of stringent regulatory structures arguably gives Ghanaian filmmakers a considerable latitude to churn out odd and insubstantial contents for public consumption. On that basis, it can be argued that contemporary filmmakers in Ghana have not considerably made significant strides in imparting the thoughts, values, and ideas of national culture, but have directed their narratives towards the parochial interests of film consumers or audiences for the returns of capital. The dominant thematic concerns in Ghanaian film texts depict storylines that are considerably unrealistic and a fictional representation of the Ghanaian society. The narratives in these film texts considerably pontificate in their reflections and mediations, which compels audiences to take sides with characters. Consequently, the major postmodern themes in Ghanaian video texts often demonize and misrepresent Ghanaian local traditions, neglect the virtues of national culture, and strengthen colonial cultural supremacy and perceptions of "African savagery”.

\section{REFERENCES}

Aveh, A. (2010). The Rise of the Video Film Industry and its Projected Social Impact on Ghanaians. Film in African Literature Today (28): 122-132.

Amad, P. (2013). Visual riposte: looking back at the return of the gaze as postcolonial theory's gift to film studies. Cinema Journal. (p.50).

Haynes, J. (2012). A bibliography of academic work on Nigerian and Ghanaian video films. Journal of African Cinemas, 4(1), 99-133. 
Haynes, J. M. (2007). Video Boom: Nigeria and Ghana. Postcolonial Text, 3(2).

Marwick, A. (1989). The nature of history. Macmillan.

Meyer, B. (2015). Sensational movies: video, vision, and Christianity in Ghana. University of California Press.

Meyer, B. (2002). Pentecostalism, Prosperity, and popular cinema in Ghana. Culture and religion, 3(1), 67-87. Nanbigne, V. "Cultural (Mis) Representation in Ghanaian Video-Film Practice”. University of Uyo Journal of Cultural Research, Vol 9, No.2 (2013): 13.

Nash, G., Kerr-Koch, K., \& Hackett, S. (Eds.). (2013). Postcolonialism and Islam: Theory, literature, culture, society, and film. Routledge, (p.2).

Ponzanesi, S. (2018). "Postcolonial Theory in Film". Cinema and Media Studies, Oxford Bibliographies. (p.1)

Ogunleye, F. (Ed.). (2003). African video film today. Integritas Services.

Owusu, J. O. (2015). Ghanaian women and film: An examination of female representation and audience Reception.

Rukundwa, L. S., \& Van Aarde, A. G. (2007). The formation of postcolonial theory. HTS Teologiese Studies/Theological Studies, 63(3), 1174.

Ukadike, F. N. Black African Cinema. University of California Press, (1994): 24.

Yanney, A. Gold Coast Colonial Films, The Mirror Newspaper (September 5, 1973): 3-4.

Video Texts

Kyeiwaa (2006)

Asoreba (2007)

Hard Target (2018)

In 6 months (2018)

The Game (2010)

Hot Fork (2010)

Marijata (2000)
- $\quad$ Danfo B.A

- $\quad$ Samuel Nyamekye

- $\quad$ Samuel Appiah

- $\quad$ Eastwood Asempa

- $\quad$ Frank Rajah Arase

- $\quad$ Socrate Sarfo.

- $\quad$ Harry Laud. 